\title{
An asymptomatic orthodontic bracket in the mandibular alveolar bone region
}

\author{
Rampalli Viswa Chandra, ${ }^{1}$ Naveen Anumala, ${ }^{1}$ Venapally Vikrant ${ }^{2}$
}

${ }^{1}$ Department of Periodontics, SVS Institute of Dental Sciences, Mahabubnagar, Andhra Pradesh, India ${ }^{2}$ Vikrant Dental Hospital Andhra Pradesh, India

\section{Correspondence to}

Dr Naveen Anumala, naveen. anumala@gmail.com
To cite: Chandra RV Anumala N, Vikrant V. BMJ Case Rep Published online: [please include Day Month Year] doi:10.1136/bcr-2013009866

\section{DESCRIPTION}

Orthodontic appliances have a propensity towards loosening, dislodgement or displacement into the surrounding hard and soft tissues. Ingestion or aspiration of orthodontic materials such as brackets, archwires, elastic separators and parts of complex orthodontic appliances have been described in dental literature. Orthodontic brackets have been found lodged in the upper lip, ${ }^{1}$ lost in the airway ${ }^{2}$ and dislodged in the soft tissues overlying a sagittal split osteotomy site. ${ }^{3}$ However, in dental literature, there seems to be no report of an orthodontic bracket displaced into an intraosseous area. We describe a case concerning a 26-year-old woman who reported to a private clinic with a request to resume orthodontic therapy after a 6-month period of discontinued treatment. A standard orthopantomograph (OPG) and lateral cephalogram of the patient were obtained which showed an intriguing presence of what appeared to be an orthodontic bracket in the osseous area corresponding to the mandibular left first-premolar region (figure 1). The bracket was not visible but was palpable from the outside and there were no clinical and radiographic signs suggestive of inflammation, infection or suppuration.

Because foreign bodies are associated with prolonged inflammation and risk of infection, the bracket was retrieved by 'guttering' the bone around it after raising a full thickness mucoperiosteal flap. Intraoperatively, the stainless steel bracket was found fenestrating through the buccal cortical plate at the level of the middle thirds of the adjacent root surfaces (figure 2). In this subject, the brackets were

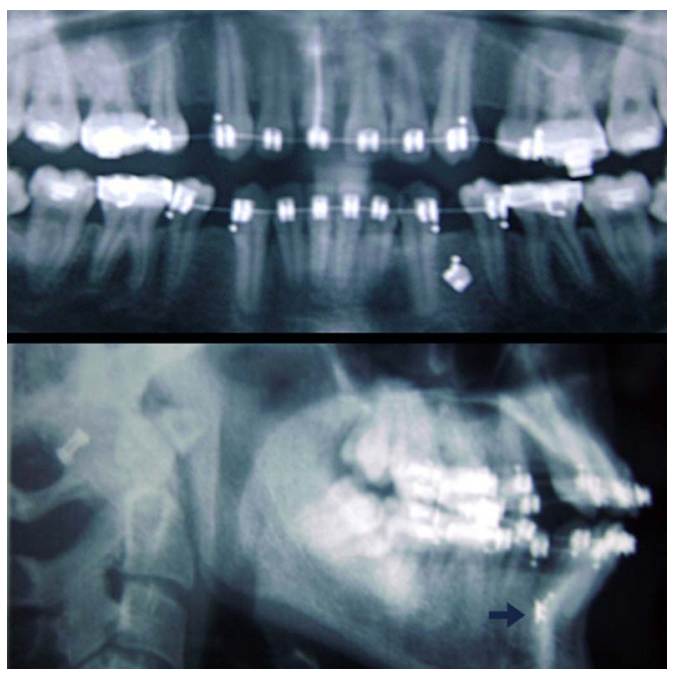

Figure 1 Views from the OPG and lateral cephalogram demonstrating the intraosseous displacement of an orthodontic bracket.

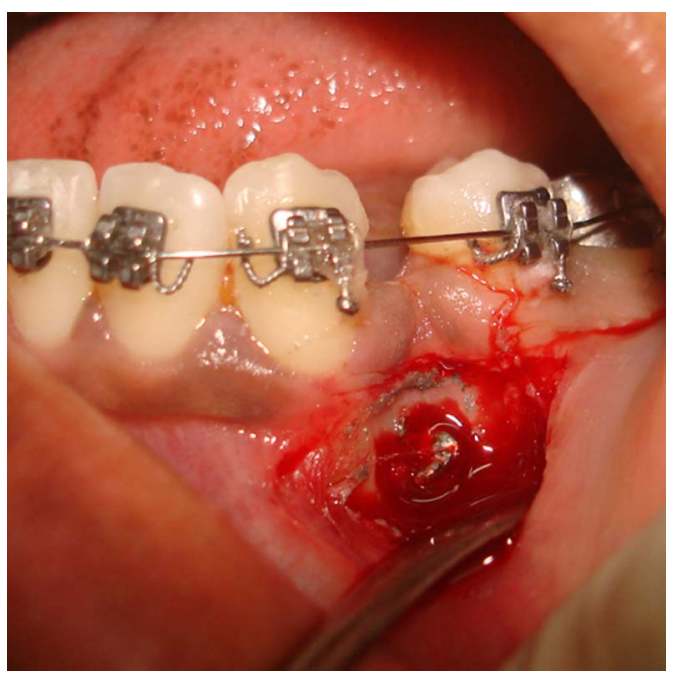

Figure 2 The stainless steel bracket surrounded by granulation tissue was found fenestrating through the buccal cortical plate.

bonded at the beginning of treatment and the orthodontic extractions were performed at a later date. It can be theorised that the actual displacement event might have happened when a loose bracket dropped into the extraction socket. A practitioner's goal is to prevent the occurrence of this significant problem thus avoiding the unpleasant medical and medicolegal consequences of retained foreign bodies.

\section{Learning points}

- Brackets can displace or dislodge into adjacent anatomical regions and the alveolar bone is not an exception.

- Asymptomatic presentation of a foreign body is not uncommon, and an impromptu inventory of appliances during every visit might potentially identify missing components.

- Surgical removal might be warranted to prevent prolonged inflammation, risk of infection and allergic reactions.

- If encountered, a careful examination should be carried out for acute clinical and medicolegal reasons and removal may mitigate this risk and reduce the morbidity and mortality associated with a foreign body.
Contributors VV and RVC were the primary caregivers to the subject in the case report. NA prepared the manuscript.

Competing interests None. 
Patient consent Obtained.

Provenance and peer review Not commissioned; externally peer reviewed.

\section{REFERENCES}

1 Conti G, Dolci M, Borgonovo A, et al. Aesthetic restoration of upper lip after removal of post-trauma foreign body (orthodontic bracket). Eur J Paediatr Dent 2012;13:239-40.
2 Laureano Filho JR, Godoy F, O'Ryan F. Orthodontic bracket lost in the airway during orthognathic surgery. Am J Orthod Dentofacial Orthop 2008;134:288-90.

3 Macey-Dare L. A case report: dislodgement of an orthodontic bracket into a sagittal split site. J Orthod 2001;28:68.

Copyright 2013 BMJ Publishing Group. All rights reserved. For permission to reuse any of this content visit http://group.bmj.com/group/rights-licensing/permissions.

BMJ Case Report Fellows may re-use this article for personal use and teaching without any further permission.

Become a Fellow of BMJ Case Reports today and you can:

- Submit as many cases as you like

- Enjoy fast sympathetic peer review and rapid publication of accepted articles

- Access all the published articles

- Re-use any of the published material for personal use and teaching without further permission

For information on Institutional Fellowships contact consortiasales@bmjgroup.com

Visit casereports.bmj.com for more articles like this and to become a Fellow 